\title{
A Study of College English Teaching Mode Under the Concept of Innovative Entrepreneurship Education
}

\author{
*Bing $\mathrm{He}$
}

\author{
School of foreign language, Dalian Jiaotong University, DaLian, China \\ *Corresponding author e-mail: rachelhe2008@163.com
}

\begin{abstract}
To cultivate students' innovation and entrepreneurship ability is an important policy put forward by the Party and the State for college teaching in the new era. Under the new situation and according to the new requirements and measures put forward by the State, there are still some problems in College English teaching, such as insufficient awareness of education innovation, backward teaching concepts, insufficient integration of curriculum design, and imperfect evaluation system. This paper aims at the curriculum system of College English. In order to solve these problems, it is necessary to help students to establish innovative consciousness. Teachers should renew the educational concept and innovate teaching mode. Universities should build the integrated curriculum of College English with entrepreneurship and innovative awareness, establish and improve the multiple evaluation system, strengthen practical teaching, and improve college students' innovation and entrepreneurship ability.
\end{abstract}

Keywords: innovation and entrepreneurship education, College English, teaching research

\section{INTRODUCTION}

"Innovation and entrepreneurship" is a new connotation of vocational education given by our party and country with the continuous development of social economy. "Innovation and entrepreneurship education is aimed at cultivating talents with basic quality and pioneering personality, including the education of cultivating their entrepreneurship awareness, innovation spirit and innovation and entrepreneurship ability, which is essentially a practical education." What kind of people to cultivate and how to cultivate them is a serious problem raised by the Party and the State in the new period of socialist history. The talents cultivated by colleges and universities must meet the needs of socialist construction and development. The teaching objectives, personnel training programs and curriculum settings of colleges and universities should closely focus on the cultivation of students' innovation and entrepreneurship ability. In 2015, the proposal "the opinions on deepening the innovation and entrepreneurship education reform in Colleges and universities" issued by the general office of the State Council proposed that by 2020, a university innovation and entrepreneurship education system should be established, which integrate classroom teaching, autonomous learning, social practice, guidance and assistance, and cultural guidance. College English course is a compulsory basic course for college students, which is of great significance to cultivate students' foreign language ability, humanistic quality and application skills. Under the background of economic globalization, higher requirements have been put forward for College English teaching, which has gradually changed from academic and research oriented to application oriented.

\section{CURRENT PROBLEMS UNDER THE SITUATION OF INNOVATION AND ENTREPRENEURSHIP EDUCATION}

\begin{abstract}
Higher education adheres to innovation leading entrepreneurship and entrepreneurship driving employment, actively adapts to the new normal of economic development, focuses on innovative talent training mechanism, speeds up the cultivation of large-scale innovative and entrepreneurial talents with innovative spirit and the courage to commit to practice, which emphasizes both theoretical and practical training. Innovation and entrepreneurship education aims to cultivate talents with basic quality and pioneering personality, with entrepreneurship consciousness and entrepreneurship ability. Besides, the new education system aims to cultivate students' innovation thinking and entrepreneurship ability in different study levels. In the past 10 years, more than 20000 research papers have been published, focusing on the current situation of College English teaching, including teaching mode, teaching content, teaching evaluation, reform direction, etc. Although college English teaching is reforming and improving with the progress of the times, there are still many problems to be solved in traditional English teaching. In the modern society, with rapid economic change, talents with innovative spirit and entrepreneurial ability are in urgent need. To adapt to the new changes and requirements of the society, colleges and universities should deepen the reform of education and teaching, innovate the development of College English teaching guided by market demand, and improve the comprehensive quality of college students and the quality of innovation and entrepreneurship education of
\end{abstract}


college students. Although many colleges and universities have achieved good results in innovation and entrepreneurship education, there are still many problems that cannot be ignored.

\subsection{The lag of teachers' teaching concept and Curriculum}

In College English teaching, most of the teachers still focus on exam oriented teaching, pay attention to the teaching of students' language knowledge, and ignore the training of students' skills and ability. The one-way transfer of knowledge centered on teachers' teaching while ignored students' position in learning and learning needs. Therefore, it is difficult to arouse students' initiative in autonomous learning. Teachers' teaching objectives are not clear and students' autonomous learning is not enough. At present, in College English teaching, the cultivation of students' practical ability is not paid enough attention. It is only a simple theory centered teaching, which provides students with limited space for communication, leading to the weak awareness of innovation and entrepreneurship. For example, Ming Anyun [1] pointed out that the traditional one-way teaching mode is not conducive to mobilizing and giving full play to the enthusiasm and initiative of students' autonomous learning, nor conducive to the cultivation of students' comprehensive practical application ability. Wen Qiufang [2] points out that the traditional English teaching mode is not set up reasonably, and the communication effectiveness as an international lingua franca is not paid enough attention to, which leads to a large investment in College English teaching and low effectiveness.

The curriculum is only a simple addition in form in actual teaching. Although the content of innovation and entrepreneurship is involved in the curriculum, due to the disconnection between College English and innovation and entrepreneurship education curriculum, the innovation and entrepreneurship education in College English education is too intentional, and the content is far fetched, so the two education contents are not really integrated organically.

\subsection{College Students' ability of innovation and entrepreneurship is not strong}

Although most college students have certain cognition and desire for innovation and entrepreneurship, they are also willing to explore new theories and methods. However, because of some subjective and objective factors, they only stay in the theory, and do not really improve their innovation and entrepreneurship ability. Under the exam oriented teaching mode for a long time, it lacks the ability to find, raise and solve problems, the consciousness of innovation and entrepreneurship, the excessive dependence on teachers, the initiative of innovation and entrepreneurship and the creativity of learning. Even if some students have the desire to try to innovate and start a business, they are forced by the lack of social experience, their own knowledge reserve and experience, and the analysis of problems is simple and one-sided, it is difficult to solve the problems in practice.

\subsection{Lack of diversified evaluation system of College English}

In the current evaluation system, only the paper grade at the end of the period is taken as the total evaluation result, which is inevitably biased, overemphasizing the result evaluation and neglecting the process evaluation. As a result, the reform of College English teaching has no guidance and restriction, which leads to the ambiguity of teachers' teaching objectives and the lack of students' autonomous learning. Nowadays, many schools have separated the learning of English courses from the professional learning, and set the learning goal of English as passing CET-4 and CET-6, which has little to do with the professional learning. There is often a strange phenomenon that the English test level has passed, but the professional English materials still can't understand. To achieve good results in innovation and entrepreneurship, it is necessary to establish a college English evaluation system, clarify the teaching methods and assessment methods of College English teaching reform, build a teaching evaluation mechanism, and improve students' ability to use knowledge analysis and solve problems. The establishment of a new curriculum evaluation system is an important part of the reform. It is necessary to revise the training program of professional talents in time and reform the old evaluation system that does not adapt to the new normal. We should especially focus on guiding students to strengthen innovation awareness, cultivate entrepreneurship, train creativity, form a good atmosphere to promote innovation and entrepreneurship, and improve the innovation and entrepreneurship education curriculum system. [3]

\subsection{The lack of practice platform in College English Teaching}

Practical teaching is an important way to consolidate theoretical knowledge and deepen theoretical understanding. However, in the process of training entrepreneurial talents, there is no open environment, no emphasis on opening to the society and the world, and no sustainable and diversified innovation and entrepreneurship education platform. The teaching of College English is still limited by the rules and regulations of teaching materials.

\section{INNOVATE ENTREPRENEURSHIP BASED COLLEGE ENGLISH TEACHING STRATEGIES}

How to integrate the innovative education concept into College English teaching and reform the original teaching content and mode to serve the professional teaching and 
really cultivate the "foreign language + professional" compound talents with innovative quality is the future development direction of College English teaching. In view of the problems existing in the above college English teaching mode, and in order to better carry out innovation and entrepreneurship education, this paper discusses the reform of College English teaching mode from four aspects: improving students' creative consciousness, promoting teachers' English teaching concept renewal, building multidimensional evaluation system and enhancing college English practice.

\subsection{Improve students' creative consciousness}

In the teaching of College English course, we should introduce the content of entrepreneurship education in different levels and stages. Under the new mode of teaching, we should cultivate the quality, ability and knowledge that students should have in their entrepreneurial activities in a planned way and improve students' language literacy and employment ability simultaneously, which plays an important role in further strengthening the innovation and entrepreneurship education of college students. [4] It highlights the instrumental features of language and emphasizes that in the process of English learning, learners should master the new knowledge delivered by the teaching content while acquiring the language ability, which makes the focus of teaching shift from learning the language itself to learning professional knowledge in the language environment, making the language environment more authentic and the language ability more practical. Through their own classroom teaching, teachers should take the idea of innovation and entrepreneurship as the carrier through the professional teaching of College English knowledge, and cultivate college students' awareness of innovation and entrepreneurship. Students are encouraged to participate in all kinds of innovation and entrepreneurship and College English competitions, so as to improve their ability of fast learning, actively participate in various practical activities and exercise their skills.

\subsection{Under the guidance of innovation and entrepreneurship education concept, renew teaching concept}

Teachers should renew teaching ideas, deepen the awareness of innovation and entrepreneurship into their own classroom teaching. Apart from that, teachers should guide students to put forward their views on teaching content, activity forms and teaching concepts, create teaching situations, and show the value of teaching innovation ideas. [5] Classroom teaching is inseparable from a certain teaching mode. A good teaching mode can ensure the quality of teaching. In College English teaching, teachers should make use of modern teaching mode to grasp the overall value of curriculum teaching. Teachers should start from students' interest in learning, life experience and cognitive level, and pay attention to the cultivation of students' practical ability to use the language. Improve the participation rate of the classroom, promote students' selfstudy, cultivate students' self-confidence and sense of responsibility, and greatly improve the teaching effect of the classroom.

\subsection{Building a multidimensional evaluation system}

The university should establish and improve the diversified evaluation system of College English, including diagnostic evaluation, formative evaluation and summative evaluation. Students should not only master the language they have learned, but also be familiar with the entrepreneurial ideas contained in the language. The traditional summative evaluation is not suitable for the innovative teaching mode. Therefore, it is necessary to build a systematic evaluation system that matches the dual objectives. The part of teaching evaluation includes teacher evaluation, student evaluation and student mutual evaluation, which can reflect the situation of teachers teaching and students learning more comprehensively, provide a good goal for both teachers and students, and conform to the requirements of innovation and entrepreneurship education on teaching evaluation and assessment method reform.

\subsection{Enhancing the practical teaching of College English}

Interest is the best driving force for learning. The second is the lack of understanding of the importance of English learning. In a real sense, mastering a foreign language can greatly improve the added value of professional learning and enhance the depth of innovation and entrepreneurship. Establish a database, including text materials, videos, images, etc. Therefore, students can choose learning materials according to their interests and needs based on the platform, and change passive learning into active learning. In the teaching, English speech activities, word spelling contests, self-made dialogues, film dubbing, etc. can be carried out. English clubs can also be set up to enrich the students' second English class. In order to break the shackles of the classroom area, students can be organized to carry out some English Teaching in line with professional learning on the spot of professional training. We should use reasonable teaching methods to improve students' consciousness of innovation, make students connect theory with practice and improve their ability. At last, we should strengthen the training of College English teachers' innovation and entrepreneurship education teaching ability and improve the practical level of teachers' curriculum teaching. 


\section{CONCLUSION}

Colleges and universities should carry out innovation and entrepreneurship education, integrating the concept of innovation and entrepreneurship education into College English teaching, and exploring diversified college English teaching. It not only enriches College English teaching ideas and models, but also provides a platform for the establishment of practical teaching system. Entrepreneurship is a social project that needs to be adhered to for a long time, and entrepreneurship education should also face the whole society. It is the fundamental way to realize the cultivation of innovation and entrepreneurship ability to build a curriculum structure that is in line with the characteristics of talent cultivation in colleges. Besides, the new teaching system should also links up the development of regional economy and adapts to the needs of students' innovation and entrepreneurship. Of course, the organic integration of innovation and entrepreneurship education and College English teaching cannot be completed overnight, but as long as the country, society, schools and teachers work together, it will be able to achieve the national talent strategy requirements of cultivating composite talents to meet the needs of the times.

\section{REFERENCES}

[1] Ming Anyun. Feasible measures of College English Teaching Reform -- Analysis of English Graded Teaching Mode [J]. Crazy English, 2007, (2): 18-21

[2] Wen Qiufang. Challenges and solutions to college English: a curriculum perspective [J]. Foreign language teaching and research, 2012, 44 (2): 283-292

[3] Wu Xiaohong. Dilemma and reflection of College English Teaching [J]. Journal of Hunan University of science and technology, 2016, 37 (6): 137-138

[4] Zhang Na. How to integrate entrepreneurship education into College English Teaching [J]. Innovation and entrepreneurship education, 2014, (6): 46-47

[5] Qin Hongli, Wei Xin. College English Teaching Reform: individualization, discipline and Sinicization [J]. Campus English, 2018, (5): 39-40

[6] Kang Hongjun, Zhang yangziyun. Cultivation of College Students' English autonomous learning ability under the background of innovation and Entrepreneurship Education [J]. Intelligence, 2020 (02): 18Entrepreneurship Education [J]. Intelligence, 2020 (02): 18

[7] Wu Yuanyuan. Exploration of College English teaching reform in the context of innovation and entrepreneurship [J]. Industry and Technology Forum, 2019,18 (20): 206-207

[8] Ye Chang. The innovative practice of College English CLIL teaching mode -- Taking the content of innovative entrepreneurship education as an example [J]. Journal of Liaoning University of science and technology, 2019,21 (02): 76-78 